\title{
"Resituating the role of Prof KKS Namboothiri in streamlining social transformation of Yogakshema Sabha and the Malayala Brahmin community of Kerala "
}

\author{
K M Vishnu Namboodiri \\ Assistant Professor and the Head of the Department of History, Mar Thoma College, Thiruvalla, \\ India \\ namboodiri@marthomacollege.org
}

Keywords: "Yogakshema Sabha”, "Namboothiri”, “Community”, “Lobby”, "Peaceful Coexistence” .

Abstract: The paper is an attempt to delineate the contributions of Prof. Kudalmana Krishnan Sankaran Namboothiri, widely remarked as the "Father of Modern Yogakshema Sabha", the community organization of the Malayala Brahmins of Kerala. The multitalented, versatile genius had literally transformed the organization from a mere paper party to an entity of eminence in the State of Kerala. Prof. KKS is well remembered for his sharp and well worded political speeches in various fora of academic and public life. On the fifth year of his demise the present researcher is presenting a short study of the stalwart of public agitation and community leadership for the academia at large.

Kudalmana Krishnan Sankaran Namboothiri, referred and well-known all over India by the name KKS was born in an orthodox Namboothiri family at Thalavady in the present-day State of Kerala. An academician by profession Prof KKS rose to the apex of community leadership of Yogakshema Sabha and served as the President of the organization for the record number of times. His growth and positioning in the organization began with the Ramamangalam session of 1985, which was the Eight annual session of the Yogakshema Sabha since its initiation in 1976 under the presidentship of Poomulli Neelakandhan Nambudiripad. In the year 1986 KKS was again elected the president, this time from Thiruvananthapuram, the Capital of the State. The organization was emerging and through its regular media correspondences and activities through leading journals such as Mathrubhoomi and Malayala Manorama and was reaching the Brahmins of Kerala and Malayalees in general. Prof KKS insisted that "if the Namboothiri voices were to be heard it had to be Echoed from the right Places". The prayer, petition, peace model was not his cup of tea and believed in the idea of total transformation.

In 1987 and 1988 Adv V Sankara Raja led the organization, and KKS was active in organizational development, it was during this time that his writings had started to figure widely and published even from dissenting and conflicting quarters. His interest in community and Sacrament had grown over the years and now had emerged as an Acharya of the community and conducted several Shodasha ceremonies as the Chief Patron "Othikyon". It is worth remembering the fact that Prof KKS continued to be a leading academician in the field of literature all through the 
times and had even translated some of the leading historical works such as "Avasanathe Samartha Vichara” by Amanoor Madhava Chakyar into English language.

In 1989 KKS was back to power, he was unanimously elected the president at the Kalady session, his Namboothiri model speech at the session aroused the ear brows from many quarters, he asserted for the Namboothiri Identity and Namboothiri Perspective in this session. The Political leadership of Kerala and its minority pacification was widely criticised by him. Ayyamkudy, Manjeri and Guruvayur Sessions of 1992, 1993 and 1994 respectively, made KKS synonymous with Yogakshema Sabha, the Political and Cultural Sway of the strongest leader of the organization was evident by now to the Nation. It was in 2003 Kottayam session that KKS once again emerged the President of Yogakshema Sabha. By the new millennium a great change in the outlook and perception of the leader was emphatically evident, from Malayala Brahmin leadership he was slowly changing his attention towards pan Indian fronts and became involved in the works and activities of All India Brahmin federation, he became the link between the Kerala community and the nation at large, through this. He was instrumental in organizing the Brahmanda Garjanam protest for lobbying and Peaceful coexistence, organized in new Delhi, which is still remarked as an epoch making event in the history of Yogakshema Sabha.

The great master toward the end of the academic career went to serve as the principal of the colleges administered by Sreesankara Trust. What KKS was for the Namboothiri Community was nothing short of a path breaker, an iconoclast and a social reformer. To conclude The Malayala Brahmin Community is lettered in the History of Kerala through Sankaras, firstly Sree Sankaracharya Acarya Swami of the Eight Century, secondly through E M Sanakraran Namboothiri Pad the first Communist Chief Minister ever elected through ballot in the world, and thirdly through Prof KKS Namboothiri who immortalized the Yogakshema Sabha activities and worked towards reforming the community and the society in general. KKS breathed his last in November 2011 at Sultanate of Oman but continues to enlighten and motivate the community and generations to follow, through his books, speeches and the dreams he showered. Quoting his own words "Man is the product of his society, if he doesn't understand it, he will be doomed to understand it when the time toggle his nerve”

\section{References}

[1] Gayathri, Monthly Journal of Kannur District Yogakshema Sabha, 2008-2010

[2] Mughadarsanam, Journal of Kannur District Yogakshema Sabha, 2008-2013

[3] Prajnanam, Souvenir of Yogakshema Sabha State Conference, Kollam,2013

[4] Panchaksharam Journal of Yogakshema Sabha State Committee,2008-2013

[5] Pavithram, Journal of Ernakulum District Yogakshema Sabha, 2005-2013

[6] Pavithram, Souvenir, Payyannur Grama Samajam,

[7] http://www.namboothiri.com/articles/yogakshema-sabha-annual-days.htm 